\title{
Beta-cyclodextrin derivatives as carriers to enhance the antiviral activity of an antisense oligonucleotide directed toward a coronavirus intergenic consensus sequence
}

\author{
S. Abdou, J. Collomb, F. Sallas, A. Marsura, and C. Finance \\ GEVSM, EA 1123, Université Henri Poincaré - Nancy 1, Faculté de Pharmacie, \\ Nancy, France
}

Accepted March 17, 1997

Summary. The ability of cyclodextrins to enhance the antiviral activity of a phosphodiester oligodeoxynucleotide has been investigated. A 18-mer oligodeoxynucleotide complementary to the initiation region of the mRNA coding for the spike protein and containing the intergenic consensus sequence of an enteric coronavirus has been tested for antiviral action against virus growth in human adenocarcinoma cells. The phosphodiester oligodeoxynucleotide only showed a limited effect on virus growth rate (from 12 to $34 \%$ viral inhibition in cells treated with 7.5 to $25 \mu \mathrm{M}$ oligodeoxynucleotide, respectively, at a multiplicity of infection of 0.1 infectious particle per cell). In the same conditions, the phosphorothioate analogue exhibited stronger antiviral activity, the inhibition increased from 56 to $90 \%$. The inhibitory effect of this analogue was antisense and sequence-specific. Northern blot analysis showed that the sequence-dependent mechanism of action appears to be the inhibition of mRNA transcription. We conclude that the coronavirus intergenic consensus sequence is a good target for an antisense oligonucleotide antiviral action. The properties of the phosphodiester oligonucleotide was improved after its complexation with cyclodextrins. The most important increase of the antiviral activity (90\% inhibition) was obtained with only $7.5 \mu \mathrm{M}$ oligonucleotide complexed to a cyclodextrin derivative, 6-deoxy-6-S- $\beta$-D-galactopyranosyl-6-thio-cyclomaltoheptaose in a molar ratio of $1: 100$. These studies suggest that the use of cyclodextrin derivatives as carrier for phosphodiester oligonucleotides delivery may be an effective method for increasing the therapeutic potential of these compounds in viral infections.

\section{Introduction}

The use of antisense oligonucleotides is an interesting approach to study cellular and viral gene function and to block gene expression $[2,3,60]$. Oligonucleotides have been considered as ideal agents for inhibiting viral 
replication due in part to their high specificity for viral DNA and RNA sequences. These agents have been successfully employed to block the replication and cellular expression of several viruses, including herpes simplex virus [20], cytomegalovirus [43] and especially human immunodeficiency virus [33]. However, the vulnerability of oligonuleotides to nucleases' attack, combined with their intracellular distribution and uptake properties, have limited their therapeutic potential. To avoid the problem of nucleases' digestion and to improve the cellular uptake of oligonucleotides, either chemical modifications of the internucleoside phosphodiester linkages [35] or of the ribose sugar [25] and various oligonucleotide conjugates have been tested. One chemical analog that is widely employed for enhanced stability is the phosphorothioate oligonucleotide. But, although this analog has increased resistance to degradation in vivo and in vitro $[1,46,59]$ it has exhibited sequence-specific and non sequence-specific activities [11, 54, 55]. The oligonucleotide conjugates include oligonucleotide adsorbed onto poly (isobutylcyanoacrylate) nanoparticles [40], encapsulated in liposomes [23] or conjugated to the cholesterol $[18,26]$. These strategies have resulted in an increase of the cellular uptake of oligonucleotide and/or stability against nucleases. However, the inherent properties of the cholesterol, liposomes or nanoparticles carriers led to increase the immunogenicity of the oligonucleotide complex and the tendency of the complex to be phagocytosed by the reticuloendothelial system [44].

Investigations in cyclodextrin chemistry field have been increased since several decades. Cyclodextrins are molecular hosts acting as carriers. It frameworks describes a group of cyclic polysaccharides containing 6 to 8 glucose units in $\alpha-(1,4)$ linkage $(\alpha-C D, \beta-C D$ and $\gamma$-CD have respectively 6,7 or 8 glucose units). They possess an hydrophobic internal cavity which can include various small molecules and a peripheral structure containing a large number of hydroxyl groups making the molecule water soluble. The cyclodextrins form complexes with numerous compounds and $\beta$-cyclodextrin is the most employed for numerous applications. A wide variety of cyclodextrins and derivatives has been studied to enhance the solubility and the availability of various water-soluble and water-insoluble pharmacological agents $[6,9,21,38,64]$. This approach using cyclodextrin derivatives has been recently studied to increase the cellular uptake of phosphorothioate oligonucleotides [65]. In this work, we have investigated the ability of native $\beta$ - and $\gamma$ cyclodextrins and $\beta$-cyclodextrin derivatives as carriers to enhance the antiviral activity of a phosphodiester oligonucleotide directed toward the initiation region of the mRNA coding for the spike protein and containing the intergenic consensus sequence of an enteric coronavirus.

\section{Materials and methods}

Chemicals

The native cyclodextrins were purchased from Roquette-frères (Dijon, France) for $\beta$ cyclodextrin ( $\beta$-CD) and from Wacker-chemie GmbH, (Lyon, France) for $\gamma$-cyclodextrin 
$(\gamma-\mathrm{CD})$. The chemically modified cyclodextrins were synthetised in our laboratory according to [17] for 6-deoxy-6-S- $\beta$-D-galactopyranosyl-6-thio-cyclomaltoheptaose (SGal- $\beta-C D)$ and heptakis (6-deoxy-6-S- $\beta$-D-galactopyranosyl)-6-thio-cyclomaltoheptaose (7(S-Gal)- $\beta-C D)$ or to [39] for heptakis [6-deoxy-6-(1-2-amino) ethylamino]-cyclomaltoheptaose (7(ethane-diamino)- $\beta$-CD). All the derivatives were soluble in distilled water and sterilized by filtration through a $0.22 \mu \mathrm{m}$ membrane (Millipore, France) before use. Their chemical structures are presented in Fig. 1.

Oligonucleotides were purchased from Appligene (Strasbourg, France). An antisense sequence ( $3^{\prime}$ TGGTATTAGATTTGTACA $\left.5^{\prime}\right)$, synthetized as natural phosphodiester $\left(\mathrm{O}^{-}\right.$oligo $)$and phosphorothioate analog $\left(\mathrm{S}^{-}\right.$oligo), a sense sequence $\left(5^{\prime}\right.$ ACCATAATCTAAACATGT $3^{\prime}$ ), synthetized as phosphorothioate analog $\left(\mathrm{S}^{+}\right.$oligo) and a random sequence ( $5^{\prime}$ GAATTGTGATATTTCATG $\left.3^{\prime}\right)$, synthetized as phosphorothioate analog ( $\mathrm{S}^{\mathrm{r}}$ oligo) have been tested. All these oligonucleotides were purified by HPLC, lyophilized and the powder was dissolved in distilled water.

\section{Virus and cells}

The F15 strain of Bovine Enteric Coronavirus (BECV) was obtained from Laporte (INRA, Jouy-en-Josas, France) and propagated in the human rectal adenocarcinoma tumor cell line (HRT-18) grown in RPMI 1640 medium (ICN Biomedicals Inc., Costa Mesa, CA, USA) supplemented with $2 \%$ foetal calf serum (FCS) (Life Technologies, Eragny, France), $10 \mu \mathrm{g} /$ $\mathrm{ml}$ ofloxacin as antibiotic (Roussel Uclaf, Romainville, France) and incubated at $37^{\circ} \mathrm{C}$ for 3 or 4 days in a humidified atmosphere containing $5 \% \mathrm{CO}_{2}[30,31]$.

\section{Preparation of the [oligonucleotide-cyclodextrin]complexes}

The complexes were prepared taking in account the $\beta$ - and $\gamma$-cyclodextrins solubility data according to Higuchi and Connors [19].

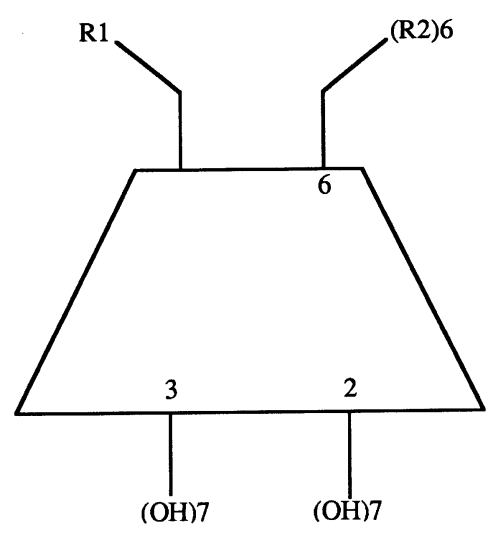
$\beta-C D$
$\mathrm{R} 1=\mathrm{R} 2=\mathrm{OH}$
S-Gal- $\beta$-CD
$\mathrm{R} 1=\mathrm{S}-\beta-\mathrm{D}-\mathrm{Galactopyranosyl}$ $\mathrm{R} 2=\mathrm{OH}$
7(S-Gal)- $\beta$-CD
$\mathrm{R} 1=\mathrm{R} 2$ = S- $\beta-\mathrm{D}-$ Galactopyranosyl
7(ethane-diamino)- $\beta-C D$
$\mathrm{R} 1=\mathrm{R} 2=-\mathrm{NH}-\left(\mathrm{C}_{2} \mathrm{H}_{4}\right)-\mathrm{NH}_{2}$

Fig. 1. Structure of the native $\beta-C D$ and $\beta-C D$ derivatives. Cyclodextrins are regular cyclic oligosaccharidyl molecules exhibiting a tronconic ring which are for simplicity represented by a truncated cone with the wider side formed by the secondary 2 - and 3-hydroxyl groups and the narrower side by the primary 6-hydroxyl 
A volume of $7.5 \mu \mathrm{M}$ phosphodiester oligonucleotide $\left(\mathrm{O}^{-}\right.$oligo $)$was added to $75 \mu \mathrm{M} \beta$ $\mathrm{CD}, 75 \mu \mathrm{M} \gamma-\mathrm{CD}, 7.5$ to $750 \mu \mathrm{M}$ S-Gal- $\beta-\mathrm{CD}, 75 \mu \mathrm{M} 7$ (S-Gal)- $\beta$-CD or $75 \mu \mathrm{M}$ 7(ethanediamino)- $\beta-C D$ in a $0.5 \mathrm{ml}$ total volume of RPMI 1640 medium. The solutions were mixed overnight at $25^{\circ} \mathrm{C}$ by vortexing at $200 \mathrm{rpm}$ with a Rotatest 74401 apparatus (BioblockScientific, Illkirch, France) and the resulting complexes were immediately tested [51]. Complex formation has been controlled by circular dichroïsm measurement and observation of oligonucleotide absorbance intensity at $260 \mathrm{~nm}$ (data not shown).

\section{Cytotoxicity assays}

The cellular viability was evaluated by the modified MTT assay as previously described [4]. HRT-18 cells were grown at confluence in 96-well flat bottom culture plates (Costar, Cambridge, MA, USA) at $4 \times 10^{4}$ cells per well and treated with varying concentrations of oligonucleotides ( 1 to $100 \mu \mathrm{M})$ or native cyclodextrins ( 1 to $8 \mathrm{mM})$ or CD derivatives $(0.1$ to $1 \mathrm{mM}$ ) for $16 \mathrm{~h}$ at $37^{\circ} \mathrm{C}$. At the end of the incubation period, the cytotoxic effect of the drug was evaluated by determination of the mitochondrial dehydrogenase activity using the MTT, 3-(4,5-dimethylthiazol-2-yl)-2,5-diphenyl-2H-tetrazolium Bromide (Sigma Chemical Co., St Louis, MO, USA). The absorbance of the solubilized material was determined using a Titertek Multiscan MCC/340 MK II apparatus (Labsystems, Helsinki, Finland). A cytotoxic effect corresponds to a decrease in purple formazan production. Results shown are the average from three experiments.

\section{Antiviral assays}

HRT-18 cells were exposed for $1 \mathrm{~h}$ at $37^{\circ} \mathrm{C}$ to various concentrations of free oligonucleotides or oligonucleotides complexed with cyclodextrins and, at the same time, were inoculated with a BECV suspension at multiplicities of infection (MOI) of $0.1,1$ or $10 \mathrm{PFU} /$ cell (Plaque Forming Units / cell). At 16 h post-infection, the virus titration was performed by the plaque forming assay using crystal violet for visualization, as previously described [30, 31, 61]. In interpreting viral titers, confidence intervals were determined and were taken into consideration [7].

\section{Isolation and northern blot analysis of viral mRNAs}

Intracellular RNAs were extracted from infected HRT-18 cells by the acid guanidinium thiocyanate-phenol-chloroform method [12] using a commercial "Message systems" kit (Bioprobe Systems, Montreuil-sous-Bois, France). The RNA pellets were dissolved in nuclease free water and adjusted to $2.2 \mathrm{M}$ formaldehyde - 50\% formamide in MOPS (morpholinepropane sulfonic acid) buffer (20 mM MOPS pH 7.0, $5 \mathrm{mM}$ sodium acetate, $1 \mathrm{mM}$ EDTA). Samples were denatured at $65^{\circ} \mathrm{C}$ for $10 \mathrm{~min}$ and analyzed by electrophoresis in $1 \%$ agarose gel and $2.2 \mathrm{M}$ formaldehyde - MOPS buffer as previously described [37]. After electrophoresis, the gel was treated with $50 \mathrm{mM} \mathrm{NaOH}$ for $20 \mathrm{~min}$, soaked in DEPC (diethylpyrocarbonate) treated water, then in $20 \times \mathrm{SSPE}(1 \times \mathrm{SSPE}$ is $3.6 \mathrm{M} \mathrm{NaCl}, 0.2 \mathrm{M}$ sodium phosphate $\mathrm{pH} 7.7,0.02 \mathrm{M}$ EDTA) for $45 \mathrm{~min}$. RNAs were transfered overnight on a hybond-N nylon membrane (Amersham, Buckinghamshire, England) in $20 \times$ SSPE, then baked at $80^{\circ} \mathrm{C}$ for $2 \mathrm{~h}$. Nylon membrane was prehybridized for $2 \mathrm{~h}$ at $42^{\circ} \mathrm{C}$ in plastic bags containing a solution of $50 \%$ formamide $-5 \times$ Denhardt's solution $(1 \times$ is $0.02 \%$ Ficoll, $0.02 \%$ polyvinylpyrrolidine, $0.02 \%$ bovine serum albumine) $-0.5 \%$ SDS $-5 \times$ SSPE and $200 \mu \mathrm{g} / \mathrm{ml}$ of sonicated calf thymus DNA. Hybridization was done overnight in the same solution at $42{ }^{\circ} \mathrm{C}$ using a $\left[{ }^{32} \mathrm{P}\right]$ DNA probe prepared by random-primed labelling of gel 
purified BECV $3^{\prime}$ end specific cDNA fragment $(1.8 \mathrm{~Kb})$ as previously described $[13,47]$. The membrane was washed twice at room temperature for $10 \mathrm{~min}$ in $2 \times \mathrm{SSPE}, 0.1 \%$ SDS then once at $65^{\circ} \mathrm{C}$ for $15 \mathrm{~min}$ in $1 \times \mathrm{SSPE}, 0.1 \%$ SDS and then once at $65^{\circ} \mathrm{C}$ for $10 \mathrm{~min}$ in 0.1 SSPE, $0.1 \%$ SDS. The membrane was air-dried and autoradiographed on X-ray film (Kodak X Omat AR-5, N.Y, USA).

\section{Results}

\section{Antiviral activity of the oligonucleotides}

Influence of oligonucleotides on the cell viability

These effects were evaluated by the MTT assay after $16 \mathrm{~h}$ of treatment of the HRT-18 cells with increasing concentrations (1 to $100 \mu \mathrm{M})$ of each oligonucleotide. Figure 2 shows that $\mathrm{S}^{\mathrm{r}}, \mathrm{S}^{-}$and $\mathrm{O}^{-}$oligonucleotides exhibited no inhibitory effect on the viability of the cells at any concentration tested.

\section{Antiviral activity of oligonucleotides in function of concentration}

The antiviral activities of the antisense phosphodiester $\left(\mathrm{O}^{-}\right.$oligo) and its phosphorothioate analog ( $\mathrm{S}^{-}$oligo) were evaluated as described in Materials and methods. HRT-18 cells were exposed to various oligonucleotide concentrations $(2.5 \mu \mathrm{M}$ to $25 \mu \mathrm{M})$ and, at the same time, were infected by a $\mathrm{BECV}$ suspension at a MOI of $0.1 \mathrm{PFU} / \mathrm{cell}$ for $1 \mathrm{~h}$ at $37^{\circ} \mathrm{C}$. At $16 \mathrm{~h}$ postinfection the virus titers of the treated infected cells were determined comparatively to those obtained with control infected cells. We observed

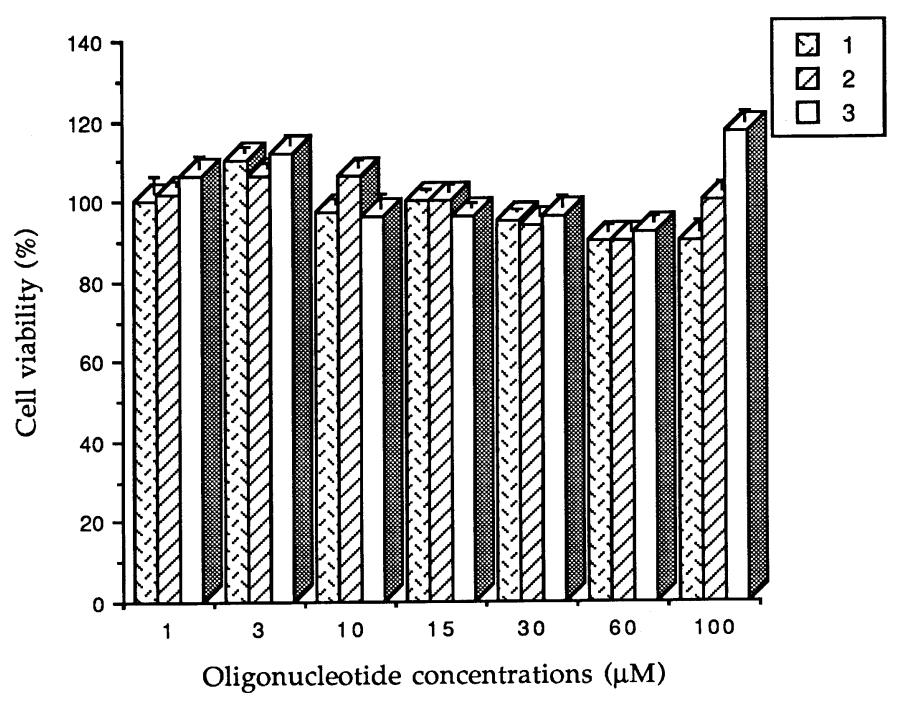

Fig. 2. Influence of oligonucleotides on cell viability. Cells grown to confluence $\left(4.10^{4}\right.$ cells/well) were treated for $16 \mathrm{~h}$ with $\mathrm{S}^{\mathrm{r}}(1), \mathrm{S}^{-}(2)$ and $\mathrm{O}^{-}(3)$ oligonucleotides at concentrations ranging from 1 to $100 \mu \mathrm{M}$. Cell viability was evaluated by their dehydrogenase activity (MTT assay). Each point is the mean of three independent experiments performed in triplicate and error bars represent standard error of mean 


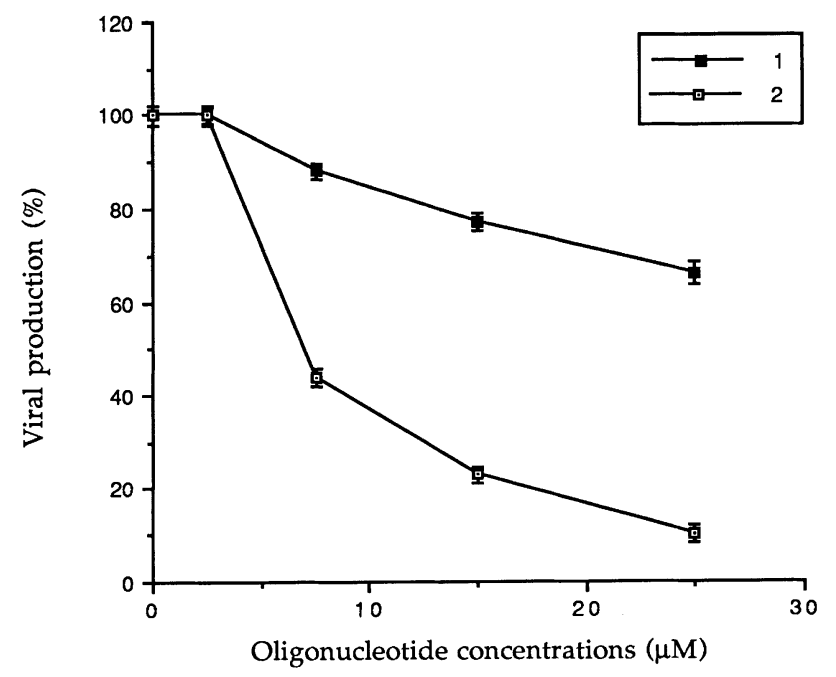

Fig. 3. Antiviral activity of the antisense oligonucleotides in function of their concentrations. Infected cells $(\mathrm{MOI}=0.1 \mathrm{PFU} /$ cell) were incubated for $16 \mathrm{~h}$ with various concentrations $(2.5$ to $25 \mu \mathrm{M}$ ) of $\mathrm{O}^{-}$oligo (1) or $\mathrm{S}^{-}$oligo (2). The virus titers were determined by the plaque forming assay. Each point is the mean of three independent experiments performed in triplicate and error bars represent standard error of mean

(Fig. 3) about 88 to $66 \%$ of viral production when cells were treated with 7.5 to $25 \mu \mathrm{M}$ of $\mathrm{O}^{-}$oligo. In contrast the $\mathrm{S}^{-}$oligo significantly reduced the ability of BECV to form plaques on HRT-18 cells. When cells were treated with 7.5 to $25 \mu \mathrm{M}$ of the $\mathrm{S}^{-}$oligo, from 44 to $10 \%$ of viral growth were observed comparatively to control infected cells. These results confirm that the inhibition is dose-dependent and that the phosphorothioate analogue exhibited a more pronounced antiviral activity than the phosphodiester oligodeoxynucleotide.

\section{Influence of the viral multiplicity of infection}

The antiviral activity of $25 \mu \mathrm{M}$ of $\mathrm{S}^{-}$oligo in presence of various viral MOI $(0.1,1$ or 10 PFU/cell) was also evaluated. The results are presented on Fig. 4. Respectively $10 \%$ or $34 \%$ of virus production were observed in cultures infected with 0.1 or $1 \mathrm{PFU} /$ cell. In contrast in presence of an MOI of $10 \mathrm{PFU} /$ cell, the use of $25 \mu \mathrm{M}$ of $\mathrm{S}^{-}$oligo inhibit weakly the virus infectivity, we obtained $66 \%$ of viral growth.

Sequence specific effect of the phosphorothioate oligonucleotide on the viral growth

In order to study the specificity of the antiviral activity of the phosphorothioate analogue, sense ( $\mathrm{S}^{+}$oligo), antisense ( $\mathrm{S}^{-}$oligo), and random ( $\mathrm{S}^{\mathrm{r}}$ oligo) oligonucleotides were comparatively tested. Using oligonucleotide concentrations of 15 or $25 \mu \mathrm{M}$ and a MOI of $0.1 \mathrm{PFU} / \mathrm{cell}$ we showed (Fig. 5) that in presence of $\mathrm{S}^{\mathrm{r}}$ oligo and $\mathrm{S}^{+}$oligo, no significant antiviral effect was observed, whereas $25 \mu \mathrm{M} \mathrm{S}^{-}$oligo allowed only $10 \%$ of viral production. These results confirm the antisense sequence specificity of the $\mathrm{S}^{-}$oligo antiviral activity. 


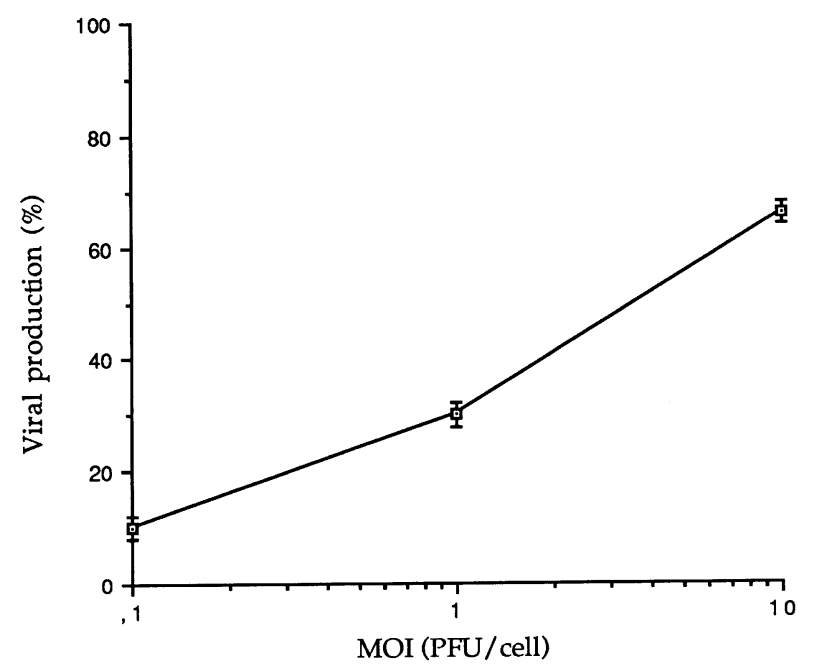

Fig. 4. Influence of the viral multiplicity of infection on the antiviral effect of the phosphorothioate oligonucleotide. Infected cells (MOI $=0.1,1$ or $10 \mathrm{PFU} / \mathrm{cell}$ ) were incubated for $16 \mathrm{~h}$ with $25 \mu \mathrm{M}$ of $\mathrm{S}^{-}$oligo. The virus titers were determined by the plaque forming assay. Each point is the mean of three independent experiments performed in triplicate and error bars represent standard error of mean

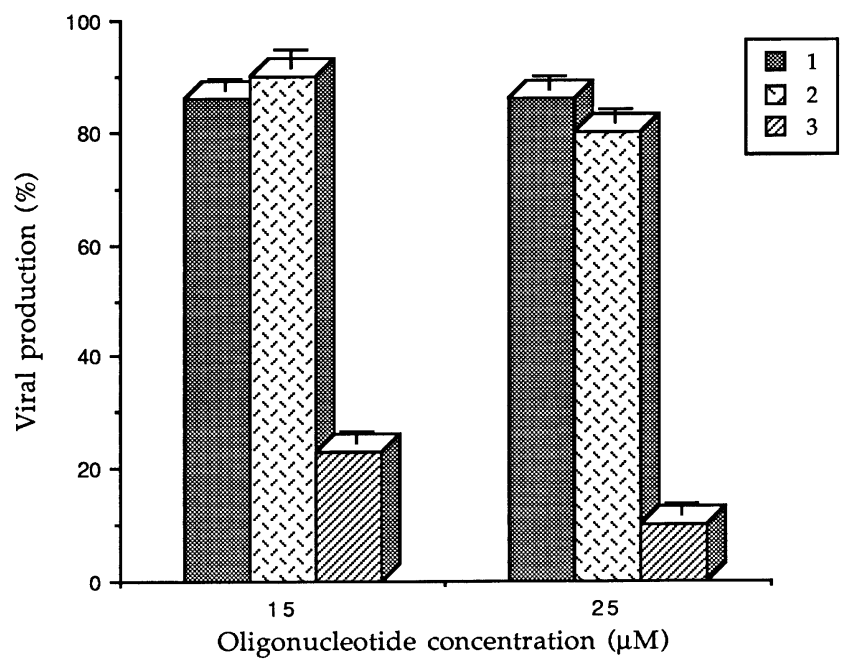

Fig. 5. Sequence specificity of the antiviral effect of the phosphorothioate oligonucleotide. Experiments were performed in presence of antisense, $\mathrm{S}^{-}$oligo (3), random, $\mathrm{S}^{\mathrm{r}}$ oligo (1) and sense, $\mathrm{S}^{+}$oligo (2). Infected cells $(\mathrm{MOI}=0.1 \mathrm{PFU} /$ cell) were incubated for $16 \mathrm{~h}$ with 15 or $25 \mu \mathrm{M}$ of oligonucleotides. The virus titers were determined by the plaque forming assay. Each point is the mean of three independent experiments performed in triplicate and error bars represent standard error of mean

Effect of the oligonucleotides on the viral mRNA synthesis

Taking into account data in which viral mRNA synthesis reached its maximal rate between 6 and $8 \mathrm{~h}$ post-infection [24], HRT-18 cells infected with BECV 
(MOI of $0.1 \mathrm{PFU} /$ cell) or mock-infected (medium containing 2\% FCS) were exposed to a $25 \mu \mathrm{M}$ either $\mathrm{S}^{-}$oligo, $\mathrm{S}^{\mathrm{r}}$ oligo or $\mathrm{S}^{+}$oligo. Each oligonucleotide and the viral suspension were added together at the same time of infection. After $7 \mathrm{~h}$ post-infection intracellular RNA extracts were separated by electrophoresis, transfered to a membrane and hybridized to a cDNA probe representing the $3^{\prime}$ end of the BECV genome (including almost all the $\mathrm{N}$ and a part of the $M$ gene) [13]

Autoradiograms (Fig. 6) showed that in infected cells, 7 RNA species could be detected at $7 \mathrm{~h}$ post-infection. These mRNAs were transcribed in nonequimolar amounts. They were named mRNA 2 to $7(2,2 \mathrm{a}, 3,4,5,6,7)$ according to decreasing order of size coding for viral proteins ns2, HE, S, ns3, ns4, $\mathrm{M}$ and $\mathrm{N}$ respectively, as already described [24]. Although the oligonucleotide had a sequence complementary to mRNA3, the synthesis of all mRNAs was significantly reduced when cells were treated with $\mathrm{S}^{-}$oligo. In the same conditions, mRNA profiles or production were not affected when cells were treated with sense oligo $\left(\mathrm{S}^{+}\right.$oligo $)$and random oligo $\left(\mathrm{S}^{\mathrm{r}}\right.$ oligo) comparatively to untreated infected cells.

\section{Antiviral activity of $\left[\mathrm{O}^{-}\right.$oligo- $\left.\mathrm{CD}\right]$ complexes}

Influence of cyclodextrins on the cell viability

The effect of native $\mathrm{CD}$ and cyclodextrin derivatives on cell viability have been tested. Native $\beta$-CD and $\gamma$-CD (Fig. 7) did not inhibit the cellular viability at concentrations varying from 1 to $8 \mathrm{mM}$. On the contrary, the $\beta$-CD stimulated the cell dehydrogenase activity, we obtained an increase of cell viability with concentrations ranging from 1 to $4 \mathrm{mM}$. Concerning the $\mathrm{CD}$ derivatives, it can be observed from Fig. 8 that S-Gal- $\beta-C D$ and $7(S-G a l)-\beta-C D$ exhibited no

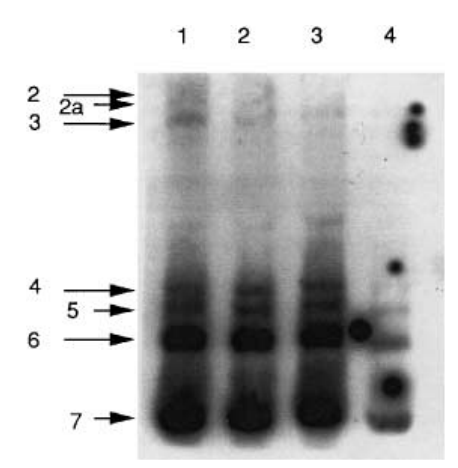

Fig. 6. Northern blot analysis of subgenomic RNAs. Intracellular RNAs were extracted at $7 \mathrm{~h}$ post-infection, separated by formaldehyde- $1 \%$ agarose gel electrophoresis and transfered to a nylon membrane. The probe was prepared by random primed $\left[{ }^{32} \mathrm{P}\right]$ labelling of enteric coronavirus-specific cDNA fragment corresponding to the $3^{\prime}$ end of genomic RNA. Autoradiograms were exposed overnight at $-80^{\circ} \mathrm{C}$ with an intensifying screen. Infected cells (MOI $=0.1 \mathrm{PFU} /$ cell) $(1)$, infected cells treated with $\mathrm{S}^{\mathrm{r}}$ oligo (2) or $\mathrm{S}^{+}$oligo (3) or $\mathrm{S}^{-}$oligo (4). Each oligonucleotide was used at a concentration of $25 \mu \mathrm{M}$ 


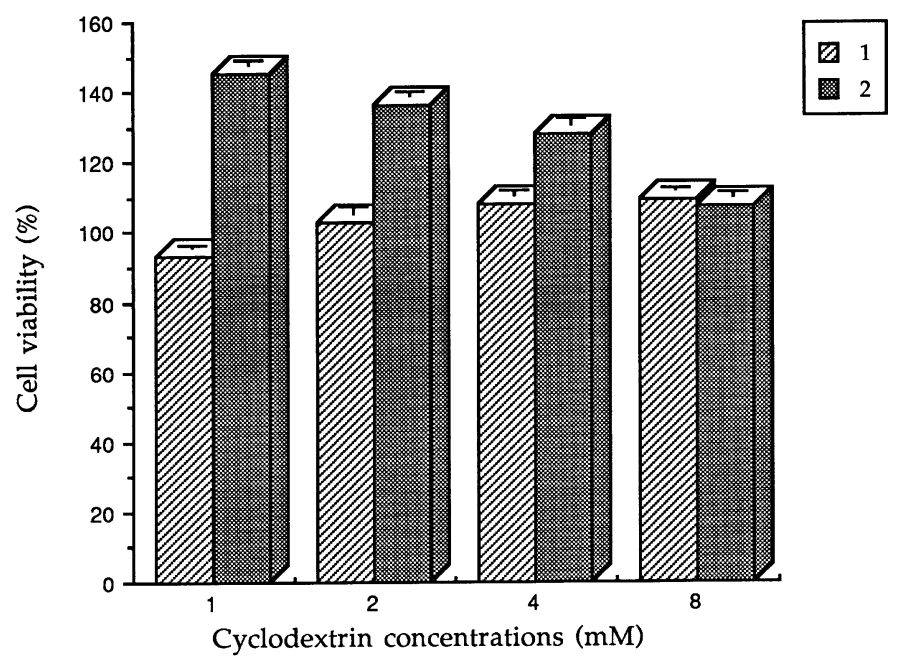

Fig. 7. Influence of native cyclodextrins on the cell viability. Cells grown to confluence $\left(4.10^{4}\right.$ cells/well $)$ were treated for $16 \mathrm{~h}$ with native cyclodextrins $\beta$-CD $(1)$ and $\gamma$-CD (2) at concentrations ranging from 1 to $8 \mathrm{mM}$. Cell viability was evaluated by their dehydrogenase activity (MTT assay). Each point is the mean of three independent experiments performed in triplicate and error bars represent standard error of mean

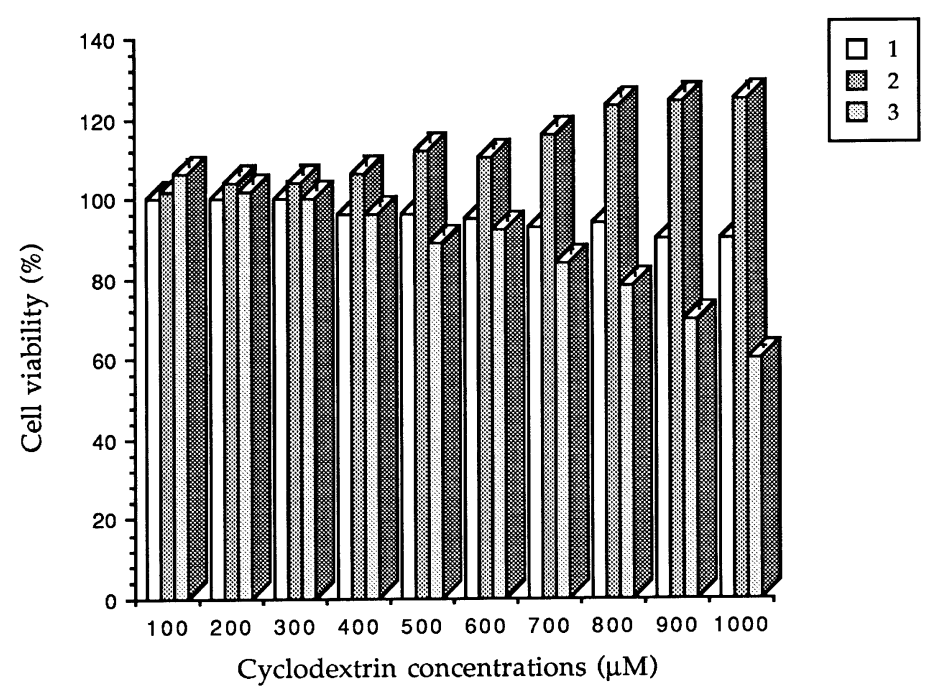

Fig. 8. Influence of cyclodextrin derivatives on the cell viability. Cells grown to confluence $\left(4.10^{4}\right.$ cells/well) were treated for $16 \mathrm{~h}$ with S-Gal- $\beta$-CD (1), 7(S-Gal)- $\beta$-CD (2) and 7 (ethane-diamino)- $\beta$-CD (3) at concentrations ranging from 100 to $1000 \mu \mathrm{M}$. Cell viability was evaluated by their dehydrogenase activity (MTT assay). Each point is the mean of three independent experiments performed in triplicate and error bars represent standard error of mean 
cytotoxic effect at concentrations varying from 0.1 to $1 \mathrm{mM}$. However, a decrease of cell viability to $40 \%$ was observed in presence of $1 \mathrm{mM}$ 7(ethanediamino)- $\beta$-CD.

\section{Effect of $\left[\mathrm{O}^{-}\right.$oligo- $\beta-\mathrm{CD}$ or $\left.\gamma-\mathrm{CD}\right]$ or $\left[\mathrm{O}^{-}\right.$oligo- $\beta-\mathrm{CD}$ derivatives] complexes on antiviral activity}

To determine if cyclodextrins could improve the activity of the phosphodiester oligonucleotide, a series of native cyclodextrins and cyclodextrin derivatives was tested. This includes $\beta-\mathrm{CD}, \gamma-\mathrm{CD}, \mathrm{S}-\mathrm{Gal}-\beta-\mathrm{CD}, 7(\mathrm{~S}-\mathrm{Gal})-\beta-\mathrm{CD}$ and 7 (ethane-diamino)- $\beta$-CD. The cells were infected $(0.1 \mathrm{PFU} /$ cell $)$ and at the same time, the various [oligonucleotide-cyclodextrin] complexes at a molar ratio of $[1: 10]$ were added. The final concentration of $\mathrm{O}^{-}$oligo was $7.5 \mu \mathrm{M}$. The viral titers were determined after $16 \mathrm{~h}$ post-infection. The results showed (Table 1) that with $\mathrm{O}^{-}$oligo the viral production was $75 \%$ which was similar to previously obtained (88\%). After complexation with cyclodextrins, the inhibition was improved, $50 \%$ of viral production was obtained with $\left[\mathrm{O}^{-}\right.$oligo$\beta-\mathrm{CD}],\left[\mathrm{O}^{-}\right.$oligo- $\left.\gamma-\mathrm{CD}\right]$ and $\left[\mathrm{O}^{-}\right.$oligo-7(ethane-diamino)- $\left.\beta-\mathrm{CD}\right]$ complexes and only $25 \%$ with $\left[\mathrm{O}^{-}\right.$oligo-S-Gal- $\left.\beta-\mathrm{CD}\right]$ and $\left[\mathrm{O}^{-}\right.$oligo-7(S-Gal)- $\left.\beta-\mathrm{CD}\right]$.

\section{Influence of the molar ratio between oligonucleotide and S-Gal- $\beta$-CD on the improvement of the antiviral activity}

We have evaluated the influence of the molar ratio between the $\mathrm{O}^{-}$oligo and the S-Gal- $\beta-C D$ on the antiviral activity of the phosphodiester oligonucleotide. $\mathrm{O}^{-}$oligo was used at a concentration of $7.5 \mu \mathrm{M}$ and S-Gal- $\beta-C D$ at concentrations ranging from $7.5 \mu \mathrm{M}$ to $750 \mu \mathrm{M}$. We showed (Fig. 9) that at molar ratio

Table 1. Antiviral activity of the phosphodiester oligonucleotide after its complexation with native cyclodextrin and $\beta$-cyclodextrin derivatives

\begin{tabular}{llclc}
\hline Compounds & $\begin{array}{l}\mathrm{PFU} / \mathrm{ml} \\
\left(\times 10^{8}\right)\end{array}$ & $\begin{array}{l}\mathrm{L}_{1} \\
\left(\times 10^{8}\right)\end{array}$ & $\begin{array}{l}\mathrm{L}_{\mathrm{u}} \\
\left(\times 10^{8}\right)\end{array}$ & $\begin{array}{l}\text { Viral } \\
\text { production } \\
(\%)\end{array}$ \\
\hline no oligo & 40 & 28.4 & 54.2 & 100 \\
$\mathrm{O}^{-}$oligo & 30 & 20.8 & 43.8 & 75 \\
{$\left[\mathrm{O}^{-}\right.$oligo- $\beta$-CD $]$} & 20 & 12.8 & 31.9 & 50 \\
{$\left[\mathrm{O}^{-}\right.$oligo- $\left.\gamma-\mathrm{CD}\right]$} & 20 & 12.8 & 31.8 & 50 \\
{$\left[\mathrm{O}^{-}\right.$oligo-S-Gal- $\left.\beta-\mathrm{CD}\right]$} & 10 & 4.8 & 18.4 & 25 \\
{$\left[\mathrm{O}^{-}\right.$oligo-7(S-Gal)- $\left.\beta-\mathrm{CD}\right]$} & 10 & 4.8 & 18.4 & 25 \\
{$\left[\mathrm{O}^{-}\right.$oligo-7 (ethane-diamino)- $\left.\beta-\mathrm{CD}\right]$} & 20 & 12.8 & 31.8 & 50 \\
\hline
\end{tabular}

HRT-18 cells were inoculated with viral suspension $(\mathrm{MOI}=0.1 \mathrm{PFU} /$ cell $)$ in presence of different complexes at molar ratio of $[1: 10]$. $\mathrm{O}^{-}$oligo concentration $=7.5 \mu \mathrm{M} ; \mathrm{CD}$ concentration $=75 \mu \mathrm{M}$. After $16 \mathrm{~h}$ post-infection, the virus titers were determined by the plaque forming assay. $L_{1}$ Lower $95 \%$ limit of confidence interval, $L_{u}$ upper $95 \%$ limit of confidence interval 


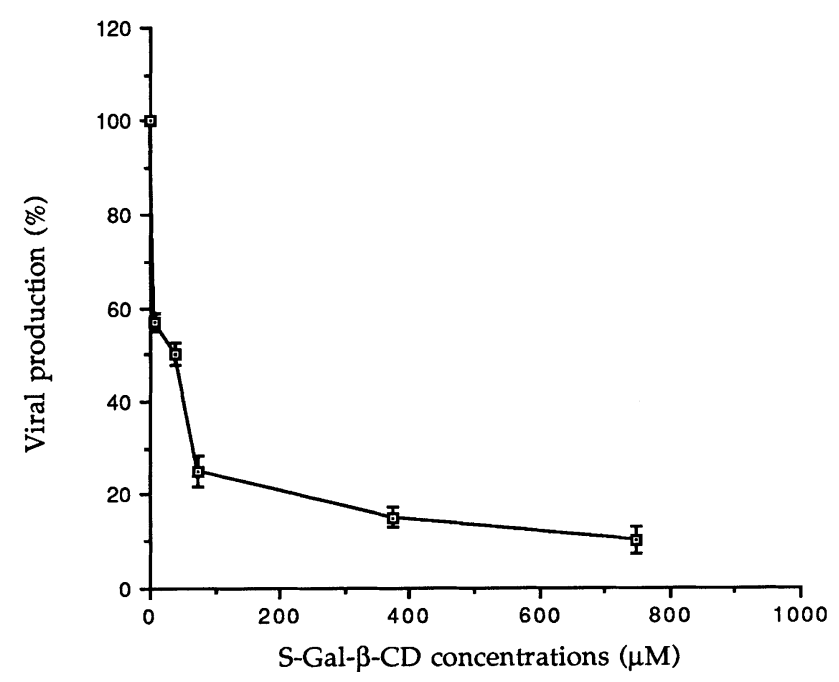

Fig. 9. Influence of the molar ratio between oligonucleotide and S-Gal- $\beta-C D$ on the antiviral activity of $\left(\mathrm{O}^{-}\right.$oligo $)$. Infected cells $(\mathrm{MOI}=0.1 \mathrm{PFU} /$ cell $)$ were incubated for $16 \mathrm{~h}$ with $\left[\mathrm{O}^{-}\right.$oligo-S-Gal- $\left.\beta-\mathrm{CD}\right]$ solutions at various molar ratio. $\mathrm{O}^{-}$oligo $=7.5 \mu \mathrm{M}$; S-Gal- $\beta-$ $\mathrm{CD}=7.5 \mu \mathrm{M}($ molar ratio $=1: 1)$ or $37.5 \mu \mathrm{M}($ molar ratio $=1: 5)$ or $75 \mu \mathrm{M}$ (molar ratio $=$ $1: 10)$ or $375 \mu \mathrm{M}$ (molar ratio $=1: 50)$ or $750 \mu \mathrm{M}$ (molar ratio $=1: 100)$. The virus titers were determined by the plaque forming assay. Each point is the mean of three independent experiments performed in triplicate and error bars represent standard error of mean

of [1:1] or [1:5], no significant antiviral activity of the $\mathrm{O}^{-}$oligo was observed (viral production equal 57 and 50\%, respectively). On the contrary the viral multiplication decreased to $25 \%, 15 \%$ and $10 \%$ when the molar ratio of $\mathrm{O}^{-}$oligo and S-Gal- $\beta-\mathrm{CD}$ was [1:10], [1:50] and [1:100], respectively.

Influence of the S-Gal- $\beta-C D$ on the viral multiplication

The effect of the S-Gal- $\beta-C D$ on the viral multiplication was evaluated. The results (Table 2) showed that no inhibitory effect in viral production was

Table 2. Effect of S-Gal- $\beta$-cyclodextrin derivative on the viral multiplication

\begin{tabular}{lllll}
\hline $\begin{array}{l}\text { S-Gal- } \beta-C D \\
(\mu \mathrm{M})\end{array}$ & $\begin{array}{l}\mathrm{PFU} / \mathrm{ml} \\
\left(\times 10^{8}\right)\end{array}$ & $\begin{array}{l}\mathrm{L}_{1} \\
\left(\times 10^{8}\right)\end{array}$ & $\begin{array}{l}\mathrm{L}_{\mathrm{u}} \\
\left(\times 10^{8}\right)\end{array}$ & $\begin{array}{l}\text { Viral } \\
\text { production } \\
(\%)\end{array}$ \\
\hline 0 & 20 & 12.0 & 30.6 & 100 \\
75 & 20 & 12.0 & 30.6 & 100 \\
375 & 25 & 16.0 & 36.7 & 125 \\
750 & 36 & 25.0 & 49.6 & 180 \\
\hline
\end{tabular}

HRT-18 cells were inoculated with viral suspension (MOI $=0.1 \mathrm{PFU} /$ cell) in presence of S-Gal- $\beta$-cyclodextrin at various concentrations. After $16 \mathrm{~h}$ post-infection the virus titers were determined by the plaque forming assay. $L_{1}$ Lower $95 \%$ limit of confidence interval, $L_{\mathrm{u}}$ upper $95 \%$ limit of confidence interval 
observed. Nevertheless with $750 \mu \mathrm{M}$, there was a significant stimulation of about $180 \%$ in viral growth.

\section{Discussion}

Coronaviruses which have an original replication procedure can be candidates for antisense strategy. These viruses cause acute and/or persistent infections and might be etiological agents for autoimmune diseases [16, 41, 45]. They are enveloped viruses which contain a single-stranded, positive-sensed polyadenylated genome. They possess three or four major structural proteins. All coronaviruses have spike $(\mathrm{S})$, membrane $(\mathrm{M})$ and nucleocapsid $(\mathrm{N})$ proteins and some have a haemagglutinin-esterase (HE) protein. In addition, there are at least four genes that encode nonstructural proteins (ns1 to 4) [29,58]. During the replication in infected cells, genomic RNA is transcribed into genomesized, negative-stranded RNA which serves as template for the synthesis of a $3^{\prime}$ coterminal nested set of 7 to 8 subgenomic mRNAs $[52,56]$ and only the $5^{\prime}$ proximal region which is not present in the next smaller RNA of the set is used for translation [48]. Another unique feature of coronavirus mRNAs is that the $5^{\prime}$ ends of genomic RNA and of all mRNAs contain a 72-77 nucleotide-long leader sequence [27, 28]. Studies made on the murine coronavirus mouse hepatitis $[10,50]$ have shown that the $3^{\prime}$ end of the leader sequence contains a repeated UCUAA pentanucleotide sequence included in the unique UCUAAAC consensus sequence (or similar sequence) observed in all intergenic regions of genomic RNA. Thus the mRNA transcriptional start is the result of the interaction between the leader sequence of the positive-stranded RNA and the complementary antileader sequence of the negative-stranded RNA [49, 50].

This intergenic consensus sequence, common to the transcription initiation sites of mRNAs could be an interesting target for an antisense oligonucleotide. We have targeted it by a 18-mer antisense oligodeoxynucleotide complementary to the initiation region of mRNA coding for $\mathrm{S}$ protein and which contains the unique UCUAAAC intergenic consensus sequence which is the promoter of genomic RNA and subgenomic mRNAs transcription [36].

We have shown that $25 \mu \mathrm{M}$ phosphorothioate antisense ( $\mathrm{S}^{-}$oligo) oligonucleotide is able to inhibit $90 \%$ of enteric coronavirus growth in HRT18 cells at a MOI of 0.1 . The intensity of the inhibitory effect of $\mathrm{S}^{-}$oligo is a function of its concentration and of the multiplicity of viral infection. In previous studies, efficient inhibition of gene expression by antisense sequence in cells requiring oligonucleotide concentrations in the range of 1 to $100 \mu \mathrm{M}$ have been reported. The great varieties in the biological models investigated render comparisons difficult $[3,8,20,32,33,43,57]$.

In the same experimental conditions, only $34 \%$ of the viral production is inhibited by the unmodified phosphodiester antisense $\left(\mathrm{O}^{-}\right.$oligo $)$oligonucleotide. The absence of a more significant inhibitory effect of this oligonucleotide may be related to its rapid degradation by nucleases and to its reduced cellular uptake. Our observations about the cellular uptake of fluorescein-conjugated 
oligonucleotides have revealed (data not shown) that only $1 \mu \mathrm{M}$ of $\mathrm{S}^{-}$oligo is quickly $(<1 \mathrm{~h})$ internalized by HRT-18 cells and that fluorescence is present both in the cytoplasm and in the nucleus of cells. In contrast, intracellular localization of even $20 \mu \mathrm{M}$ of $\mathrm{O}^{-}$oligo can not be noticed. Studies have shown $[8,22,62]$ that the uptake of oligonucleotides is a complex process which depends on many factors including cell type, structure and chemical modifications of oligonucleotides, temperature and time of incubation. This uptake is a saturable process that probably occurs through an $80 \mathrm{kD}$ protein but the true role of this protein is still unknown [5, 34]. The stronger inhibitory effect observed with $\mathrm{S}^{-}$oligo could be related to an increase in stability and in lipophilicity resulting from the replacement of the oxygen atom by sulfur [15]. It has thus been reported that phosphorothioate oligonucleotides are more strongly associated with cell membranes than the corresponding phosphodiester [8].

As previously observed $[3,20,32,33,43]$ the antiviral activity of $\mathrm{S}^{-}$oligo is not due to an oligonucleotide induced cytotoxicity. Assays to measure host-cell viability reveal that the oligonucleotides tested do not affect the level of cellular metabolism even at high concentration $(100 \mu \mathrm{M})$ which is 4 -fold in excess of inhibitory concentration $(25 \mu \mathrm{M})$.

It is noteworthy that non-sequence-specific oligonucleotides can inhibit HIV replication especially at high concentrations [53-55]. So, a random unrelated phosphorothioate oligonucleotide ( $\mathrm{S}^{\mathrm{r}}$ oligo) with the same base composition as $\mathrm{S}^{-}$oligo but without homology with any known sequence in genomic RNA shows no activity. Therefore, the inhibition of virus growth does not seem to be due to a non-sequence-specific effect. In addition a sense oligonucleotide ( $\mathrm{S}^{+}$oligo) at any concentration employed does not inhibit virus growth showing that the antiviral mechanism of action of $\mathrm{S}^{-}$oligo is antisense. These results are confirmed by northern blotting analysis in which all transcripts are significantly reduced in infected cells when $25 \mu \mathrm{M}$ of $\mathrm{S}^{-}$oligo is used. In contrast RNAs levels are unaffected by non-specific control ( $\mathrm{S}^{\mathrm{r}}$ oligo) or by sense $\left(\mathrm{S}^{+}\right.$oligo) phosphorothioate oligonucleotides. In addition, northern blotting shows that the antisense phosphorothioate $\mathrm{S}^{-}$oligo acts through a transcription inhibition mechanism in which the duplex made by hybridization of positive-stranded genomic RNA and $\mathrm{S}^{-}$oligo stops the synthesis of the full length negative stranded-RNA preventing so a subgenomic and genomic RNA synthesis. The non-inhibitory effect of the sense oligonucleotide could be explained by considering the viral replication mechanism. The transcription of the mRNA is initiated after the hybridization between the leader and anti-leader sequences. The anti-leader sequence contains the anti-consensus sequence which is the target of the sense oligonucleotide. Consequently, we assume that a competition occurs between the leader sequence and the sense oligonucleotide for hybridization to their target. This competition might be in favour of the leader sequence mainly due to its total complementarity to its target and due also to a highest affinity. Our results provide evidence that the coronavirus intergenic consensus sequence of the positive-stranded genomic RNA is a good 
target for an antisense oligonucleotide antiviral action. The inhibiting effect on virus growth is mediated by the ability of the oligonucleotide to interfere with mRNA transcription.

However, some potential disadvantages may be inherent to the use of phosphorothioate analogs. There is no assurance that substitution of a phosphorothioate for a phosphodiester in an oligonucleotide would preserve its ability to bind with similar high affinity to its target. In addition studies have shown [14] that the sulfur on phosphorothioate may provide a novel reactive center on a DNA molecule for drug interactions and this interaction may affect the efficacy of the antisense compound. It may also act by viral polymerase inhibition or by interference with viral adsorption or penetration or by inhibition of cellular enzymes or growth factors [55]. Moreover commercially phosphorothioates tend to be more expensive than the phosphodiester oligonucleotides. To avoid these problems, we attempted to improve the properties of the phosphodiester oligonucleotide by complexation with cyclodextrin supermolecules. We compared the biological activity of the phosphodiester antisense oligonucleotide $\left(\mathrm{O}^{-}\right.$oligo $)$either free or complexed with native $\beta$-CD and $\gamma$-CD or $\beta$-cyclodextrin derivatives. When the $\mathrm{O}^{-}$oligo is complexed either with native $\beta-, \gamma-C D$, or with a 7 (ethane-diamino)- $\beta-C D$ derivative, $50 \%$ decrease in viral multiplication is observed. The inhibition is higher $(75 \%)$ after its complexation with S-Gal- $\beta-C D$ or $7(\mathrm{~S}-\mathrm{Gal})-\beta-\mathrm{CD}$. Moreover, the antiviral activity of $\mathrm{O}^{-}$oligo complexed with $\mathrm{S}-\mathrm{Gal}-\beta-\mathrm{CD}$ is improved to $90 \%$ if the complexation is performed in the $\left[\mathrm{O}^{-}\right.$oligo-CD] molar ratio of $[1: 100 ; 7.5 \mu \mathrm{M}: 750 \mu \mathrm{M}]$. The same level of inhibition is obtained in presence of $25 \mu \mathrm{M}$ of $\mathrm{S}^{-}$oligo, a concentration three fold up to that used in the complex.

It has been demonstrated in the last year that substituted cyclodextrins were no longer biological amorphous compounds, but could exhibit biological activities such as antiviral activity [42, 63]. We checked that the chemical modification of $\beta-C D$ does not induce any cyclodextrin antiviral nor anticellular effect. S-Gal- $\beta-C D$ induces no inhibitory effect on the viral multiplication at the concentrations used for the preparation of the complexes. Moreover, assays to measure cell viability show no cytotoxic action of the cyclodextrins. These observations exclude the possibility that the antiviral activity obtained with the $\left[\mathrm{O}^{-}\right.$oligo-S-Gal- $\left.\beta-\mathrm{CD}\right]$ complexes is due to an effect of the S-Gal- $\beta-\mathrm{CD}$ itself.

From these results it might be concluded that the complexation of the oligonucleotide with the cyclodextrins protect the $\mathrm{O}^{-}$oligo from its degradation by the nucleases perhaps by protecting the phosphodiester group. Cellular uptake studies recently reported that the fluorescent intensity of (FITC)conjugated phosphorothioate oligonucleotides was greatly increased when the oligonucleotide was complexed with cyclodextrin derivatives, indicating that complexation increases cellular uptake [65]. In our case it might be expected that the chemical modification of the native $\beta-C D$ by substitution of the hydroxyl of the primary alcohol of one glucose unit on the ring with a thiogalactose residue improves the cellular uptake of the $\mathrm{O}^{-}$oligo by a ligand- 
carbohydrate cell receptors interaction. As the surface of numerous normal and malignant eukaryotic cells are covered with galactose-specific lectins, galactose-substituted $\beta$-CD might be used as drug carriers for targeting oligonucleotides in vivo. Another possibility which may also contribute to the enhancement of the antiviral activity of $\mathrm{O}^{-}$oligo complexed to cyclodextrin is that the complexation could modify the intracellular distribution of the antisense oligonucleotide. Probably oligonucleotide-cyclodextrin complexes enter the cells by a process different from endocytosis pathway in which the oligonucleotides may be trapped within endosomal or lysosomal vesicles. Further studies have to be achieved to study the intracellular distribution of oligonucleotide after treatment with [oligonucleotide-cyclodextrin] complexes and to elucidate the mechanism of the interaction between the oligodeoxynucleotide and cyclodextrin.

\section{Acknowledgement}

This research was supported by the French Ministère de la Recherche et des Enseignements Supérieurs, the Région Lorraine and the French Association pour la Recherche Médicale.

\section{References}

1. Agrawal S, Lyer RP (1995) Modified oligonucleotides as therapeutic and diagnostic agents. Curr Opin Biotechnol 6: 9-12

2. Agrawal S. (1996) Antisense oligonucleotides: towards clinical trials. Trends Biotechnol 14: 376-387

3. Archambault D, Stein CA, Cohen JS (1994) Phosphorothioate oligonucleotides inhibit the replication of lentiviruses and type D retroviruses, but not that of type C retroviruses. Arch Virol 139: 97-100

4. Attioui F, Al-Omar A, Leray E, Parrot-Lopez H, Finance C, Bonaly R (1994) Recognition ability and cytotoxicity of some oligosaccharidyl substituted $\beta$-cyclodextrins. Biol Cell 82: 161-167

5. Bennet CF, Chiang MY, Chan H, Shoemaker JEE, Mirabeli CK (1992) Cationic lipids enhance cellular uptake and activity of phosphorothioate antisense oligonucleotides. Mol Pharmacol 41: 1023-1033

6. Bergmann JF, Chassany O (1994) Piroxicam $\beta$-cyclodextrine: amélioration de la cinétique des médicaments par les cyclodextrines. Lett Pharmacol 8: 144-148

7. Block JC, Schwartzbrod L (1989) Viruses in water systems: detection and identification. VCH Publ., New York

8. Boiziau C, Toulmé JJ (1991) Modified oligonucleotides in rabbit reticulocytes: uptake, stability and antisense properties. Biochimie 73: 1403-1 408

9. Brewster ME, Simpkins JW, Hora MS, Stern, WC, Bodor N (1989) The potential use of cyclodextrins in parenteral formulations. J Parent Sci Technol 43: 231-240

10. Budzilowick CJ, Wilczynki S, Weiss RS (1985) Three intergenic regions of nucleotide sequence that is homologous to the $3^{\prime}$ end of the viral mRNA leader sequence. J Virol 53: $834-840$

11. Chang QY, Grill S, Egan W, Cheng YC (1993) Potent inhibition of Epstein-Barr virus by phosphorothioate oligodeoxynucleotides without sequence specification. Antimicrob Agents Chemother 37: 1420-1425 
12. Chomczynski P, Sacchi N (1987) Single-step method for RNA isolation by acid guanidium thiocyanate-phenol-chloroform extraction. Anal Biochem 162: 156-159

13. Collomb J, Finance C, Alabouch S, Laporte J (1992) Radioactive and enzymatic cloned cDNA probes for bovine enteric coronavirus detection by molecular hybridation. Arch Virol 125: 25-37

14. Copple BL, Gmeiner WM Iversen PL (1995) Reaction between metabolically activated acetaminophen and phosphorothioate oligonucleotides. Toxicol Appl Pharmacol 133: 53-63

15. Crooke, R. M. (1991) In vitro toxicology and pharmacokinetics of antisense oligonucleotides. Anticancer Drug Des 6: 609-646

16. Czerny CP, Eichorn W (1989) Characterization of monoclonal and polyclonal antibodies of bovine enteric coronaviruses: establishment of an efficient Elisa for antigen detection in feces. Vet Microbiol 20: 111-122

17. De Robertis L, Lancelon-Pin C, Driguez H, Attioui F, Bonaly R, Marsura A (1994) Synthesis of new oligosacchridyl-thio- $\beta$-cyclodextrins (CDS): A novel family of potent drug-targetting vectors. Bioorg Med Chem Lett 4: 1 127-1 130

18. Farouqui F, Sarin PS, Sun D, Letsinger RL (1991) Effect of structural variations in cholesteryl conjugated oligonucleotides on inhibitory activity toward HIV-1. Bioconjugate Chem 2: 422-426

19. Higuchi T, Connors KA (1965) Phase-solubility techniques. In: Reilley CN (ed) Advances in analytical chemistry and instrumentation, vol. 4. J Wiley, New York, pp 117-212

20. Jacob A, Duval-Vallentin G, Ingrand D, Thuong N, Helene C (1993) Inhibition of viral growth by an $\alpha$-oligonucleotide directed to the splice junction of herpes simplex virus type 1 immediate early pre-mRNA species 22 and 34. Eur J Biochem 216: 19-24

21. Jansen T, Xhonneux B, Mesens J, Borgers M (1990) Beta-cyclodextrins as vehicles in eye-drop formulations: an evaluation of their effects on rabbit corneal epithelium. Lens Eye Toxicity Res 7: 459-468

22. Jaroszewski JN, Cohen JS (1991) Cellular uptake of antisense oligodeoxynucleotides. Adv Drug Rev 6: 235-250

23. Juliano RL, Akhtar S (1992) Liposomes as a drug delivery system for antisense oligonucleotides. Antisense Res Dev 2: 165-176

24. Keck JG, Hogue BG, Brian DA, Lai MMC (1988) Temporal regulation of bovine coronavirus RNA synthesis. Virus Res 9: 343-356

25. Keller TH, Häner R (1993) Synthesis and hybridization properties of oligonucleotides containing 2'-O-modified ribonucleotides. Nucleic Acids Res 21: 4499-4 505

26. Kierg AM, Tonkinson J, Matson S, Zhao Q, Saxen M, Zhang L, Bhanya U, Yakubov L, Stein CA (1993) Modification of antisense phosphodiester oligodeoxynucleotides by a 5 -cholesteryl moiety, increases cellular association and improves efficacy. Proc Natl Acad Sci USA 90: 1048-1 052

27. Lai MMC, Baric RSS, Brayton PR, Stohlman SA (1984) Characterization of leader RNA sequences on the virion and mRNAs of mouse hepatitis virus, a cytoplasmic RNA virus. Proc Natl Acad Sci USA 81: 3626-3630

28. Lai MMC, Patton CD, Baric RS, Stohlman SA (1983) Presence of leader sequences in the mRNA of mouse hepatitis virus. J Virol 46: 1027-1033

29. Lai MMC, Brayton PR, Armen RC, Patton CD, Pugh C, Stohlman SA (1981) Mouse hepatitis virus A59: mRNA structure and genetic localization of the sequence divergence from hepatotropic strain MHV-3. J Virol 39: 823-834

30. Laporte J, Bobulesco P, Rossi F (1980) Une lignée cellulaire particulièrement sensible à la réplication du Coronavirus entérique bovin : les cellules HRT- 18. CR Acad Sci Paris Série D 290: 623-626 
31. Laporte J, L'Haridon R, Bobulesco P (1979) In vitro culture of bovine enteritic coronavirus (BEC). Les colloques de l'INSERM. Viral Enteritis 90: 99-102

32. Leiter JME, Agrawal S, Palese P, Zamecnik PC (1990) Inhibition of influenza virus replication by phophorothioate oligodeoxynucleotides. Proc Natl Acad Sci USA 87: 3430-3434

33. Lisziewicz J, Sun D, Klotman M, Agrawal S, Zamecnik P, Robert G (1992) Specific inhibition of human immunodeficiency virus type 1 replication by antisense oligonucleotides: an in vitro model for treatment. Proc Natl Acad Sci USA 89: 11 209-11213

34. Loke SL, Stein C, Zhang Xh, Mori K, Nakanishi M, Subasinghe C, Cohen JS, Neckers LM (1989) Characterization of oligonucleotide transport into living cells. Proc Natl Acad Sci USA 86: 3474-3 478

35. Lund OS, Nielsen JO, Hansen JE (1995) Inhibition of HIV-1 in vitro by C-5 propyne phosphorothioate antisense to rev. Antiviral Res 28: 81-91

36. Makino S, Joo M (1993) Effect of intergenic consensus sequence flanking sequences on coronavirus transcription. J Virol 67: 3304-3311

37. Makino S, Joo M, Makino JK (1991) A system for study of coronavirus mRNA results from intergenic site insertion. J Virol 65: 6031-6041

38. Manzoni GC, Zamfferrani C, Granella F (1989) Piroxicam $\beta$-cyclodextrin in the symptomatic treatment of primary headache. Meeting of the Interdisciplinare di Cardiologia e Neurologia Selecta Neurologia 449-453

39. Matsui Y, Yokoi T, Mochida K (1976) Catalytic Properties of Cu (II) complex with a modified cyclodextrin. Chem Lett 1037-1 040

40. Nakada Y, Fattal E, Foulquier M, Couvreur P (1996) Pharmacokinetics and biodistribution of oligonucleotide adsorbed onto poly (isobutylcyanoacrylate) nano particles after intravenous administration in mice. Pharm Res 13: 38-43

41. Onisk DV, Srikumaran S, Kelling CL, Frey ML (1991) Bovine viral diarrhoea virusspecific bovine monoclonal antibody. Arch Virol 121: 219-225

42. Otake T, Schols M, Witvouw L, Naesens L, Nakashima H, Moriya T, Kurita H, Matsumoto K, Ueba N, De Clercq E (1994) Modified cyclodextrin sulphates (mCDS11) have potent inhibitory activity against HIV and high oral bioavailability. Antivir Chem Chemother 5: 155-161

43. Pari GS, Kirkfield A, Smith J (1995) Potent antiviral activity of an antisense oligonucleotide complementary to the intron-exon boundary of human cytomegalovirus genes UL 36 and UL 37. Antimicrob Agents Chemother 39: 1157-1 161

44. Phillips NC, Emili A (1991) Immunogenicity of immunoliposomes. Immunol Lett 30: 291-296

45. Potgieter LND, McCrachen MD, Hopkins FM, Walker RD, Guy JS (1984) Experimental production of bovine respiratory tract disease with bovine diarrhea virus. Am J Vet Res 45: 1582-1585

46. Sands H, Gorey-Feret LJ, Cocuzza AJ, Hobbs FW, Chidester D, Trainor GL (1994) Biodistribution and metabolism of internally ${ }^{3} \mathrm{H}$-labelled oligonucleotides. Comparison of a phosphodiester and phosphorothioate. Mol Pharmacol 45: 932-943

47. Savoysky E, Boireau P, Finance C, Laporte J (1990) Sequence and analysis of BECV F15 matrix protein. Res Virol 141: 411-425

48. Sawiki SG, Sawiki DL (1990) Coronavirus transcription: subgenomic mouse hepatitis virus replicative intermediates function in RNA synthesis. J Virol 64: 1050-1 056

49. Sethna PB, Hofmann MA, Brian DA (1991) Minus-strand copies of replicating coronavirus mRNA contain anti-leaders. J Virol 65: 320-325

50. Shien CK, Soe LH, Makino S, Chang MF, Stohlman SA, Lai MMC (1987) The $5^{\prime}$-end sequence of the murine coronavirus genome implications for multiple fusion sites in leader-primed transcription. Virology 156: 321-330 
51. Simpkins JW (1991) Solubilization of ovine growth hormone with 2-hydroxypropyl- $\beta$ cyclodextrin. J Parent Sci Technol 45: 266-269

52. Spaan W, Cavanagh D, Horzinek MC (1988) Coronavirus: structure and genome expression. J Gen Virol 69: 2939-2952

53. Stein CA, Matsukura M, Subasinghe C, Broder S, Cohen JS (1989) Phosphorothioate oligodeoxynucleotides are potent sequence non-specific inhibitors of de novo infection by HIV. Aids Res Hum Retroviruses 5: 639-645

54. Stein CA (1995) Does antisense exist? Nature Med 1: 1119-1 121

55. Stein CA (1996) Phosphorothioate antisense oligodeoxynucleotides: questions of specificity. Trends Biotechnol 14: 147-149

56. Stern DF, Kennedy SIT (1980) Coronavirus multiplication strategy. II. Mapping the avian infectious bronchitis virus intracellular RNA species to the genome. J Virol 36: 440-449

57. Stewart AJ, Canitrot Y, Barrachini E, Dean NN, Daly RG, Cole SPC (1996) Reduction of expression of the multidrug resistance protein (MRP) in human tumor cells by antisense phosphorothioate oligonucleotides. Biochem Pharmacol 51: 461-469

58. Sturman LS, Holmes K (1983) The molecular biology of coronaviruses. Adv Virus Res 28: $35-112$

59. Temsamani J, Tang JY, Padimapriya A, Kubert M, Agrawal S (1993) Pharmacokinetics, biodistribution and stability of capped oligodeoxynucleotide phosphorothioates in mice. Antisense Res Dev 3: 277-284

60. Tonkinson JL, Stein CA (1993) Antisense nucleic-acids. Prospects for antiviral intervention. Antivir Chem Chemother 4: 193-200

61. Vautherot JF (1981) Plaque assay for titration of bovine enteric coronavirus. J Gen Virol 56: 451-455

62. Vlassov VV, Balakireva LA, Yakubov LA (1994) Transport of oligonucleotides across natural and model membranes. Biochem Biophys Acta 1197: 95-108

63. Weiner DB, Williams WV, Weisz PB, Greene MI (1992) Synthetic cyclodextrin derivatives inhibit HIV infection in vitro. Pathobiology 60: 206-212

64. Wenz G (1994) Cyclodextrin as building blocks for supramolecular structures and functional units. Angew Chem Int Edit 33: 803-822

65. Zhao Q, Temsamani J, Agrawal S (1995) Use of cyclodextrins and its derivatives as carriers for oligonucleotide delivery. Antisense Res Dev 5: 185-192

Authors' address: Dr. C. Finance, GEVSM, EA 1123, Univ. H. Poincaré, Faculté de Pharmacie, B.P. 403, F-54001 Nancy Cedex, France.

Received December 13, 1996 